\title{
Start Up Girişimlerde Girişimcilik Niyeti Üzerinde Etkili Olan Faktörler Arasındaki İlişskinin Analizi*
}

Öz

Girişimcilik, son yüzyılda araştırmacıların ilgisini çeken bir alandır; niyet, girişimcilik davranışının en önemli öncüllerindendir. Bu çalışmada start up girişimlerde, girişimcinin sahip olduğu kişisel özelliklerin (girişimci öz yeterlilik, duygusal zekâ ve risk alma eğilimi), bilişsel faktör olan girişimci davranışa yönelik tutumun ve girişimcilik niyetinin aralarındaki ilişskiler incelenmiş; araştırma, İstanbul da bulunan teknoparklarda faaliyet gösteren start up girişimciler üzerinde gerçekleştirilmiştir. Yapılan korelasyon analizi sonucu girişimci öz yeterlilik ile risk alma ĕgilimi, girişimci davranışa yönelik tutum, girişimcilik niyeti ve duygusal zeka arasında anlamlı bir ilişki olduğu; risk alma eğilimi ile girişimci davranışa yönelik tutum, girişimcilik niyeti ve duygusal zeka arasında anlamlı bir ilişsi olduğu; girişimci davranışa yönelik tutum ile girişimcilik niyeti ve duygusal zeka arasında anlamlı bir ilişsi olduğu; ayrıca giriş̧imcilik niyeti ile duygusal zeka arasında da anlamlı bir ilişki olduğu tespit edilmiştir.

Anahtar Kelimeler: Giriş̧imci Öz Yeterlilik, Duygusal Zeka, Risk Alma Eğilimi, Giriş̧imci Davranışa Yönelik Tutum, Girişimcilik Niyeti.

\section{Analysis of The Relationship Between Factors Affecting Entrepreneurship Intention in Start Up Enterprises}

\begin{abstract}
Entrepreneurship is an area that has attracted the attention of researchers in the last century; intention is one of the most important premises of entrepreneurial behavior. In this study, the relationship between the personal characteristics of the entrepreneur (entrepreneurial self-efficacy, emotional intelligence and risk-taking propensity), the attitudes towards entrepreneurial behavior (cognitive factor) and entrepreneurial intentions were examined. The research was carried out on start up entrepreneurs operating in technoparks in Istanbul. As a result of the correlation analysis, a significant relationship was found between entrepreneurial self-efficacy, risk-taking propensity, attitude towards entrepreneurial behavior, entrepreneurial intent and emotional intelligence; there is also a significant relationship between risk taking propensity and attitude towards entrepreneurial behavior, entrepreneurial intent and emotional intelligence; attitude towards entrepreneurial behavior, entrepreneurial intent and emotional intelligence have been shown to be positively correlated; it was also understood that there was a significant relationship between entrepreneurial intent and emotional intelligence.
\end{abstract}

Keywords: Emotional Intelligence, Entrepreneurial Self Efficacy, Risk-Taking Propensity, Attitudes Towards Entrepreneurial Behavior, Entrepreneurial Intent.

\footnotetext{
* Bu çalışma, İstanbul Ticaret Üniversitesi Sosyal Bilimler Enstitüsü, İşletme Ana Bilim Dalında "Yeni Kurulan İşletmelerde Girişimcilik Niyetinin Ortaya Çıkmasında Etkili Olan Faktörlerin Analizi: Ampirik Bir Çalışma" başlığıyla hazırlanan doktora tezinden türetilmiştir.

** ORCID Doktora Öğrencisi, İstanbul Ticaret Üniversitesi. İşletme Bölümü, e.banubilgiseven@gmail.com

*** ORCID Prof. Dr., İstanbul Ticaret Üniversitesi. İşletme Bölümü, mkasimoglu@ticaret.edu.tr
} 


\section{Extended Abstract}

Entrepreneurship has been a fast-growing and attractive field for scholars and management in the last century due to global competition, technological changes and developments in the market economy. While entrepreneurship was perceived as setting up a new business with one's own capital, nowadays, it has started to gain a new meaning. The concept of intent is one of the most important premises of entrepreneurial behavior. The question of why some people prefer to work in an institutional workplace while others prefer entrepreneurship led researchers to study the factors impacting entrepreneurship. In early studies, personality factors were primarily examined, but later on, entrepreneurial intent models have been developed and cognitive factors have also been included.

In this study, we aim to determine the relationship between the personal characteristics of the entrepreneur (entrepreneurial self-efficacy, emotional intelligence and risk-taking propensity), the attitudes towards entrepreneurial behavior (cognitive factor), entrepreneurial intentions were examined. We aim to understand the entrepreneurial process better by looking into entrepreneurial intent and attitudes towards entrepreneurial behavior together, and including attitude as a cognitive factor since attitude is known to be the most important indicator of entrepreneurial intent.

The study has been conducted on start-up enterprises founded as part of technoparks and the entrepreneurial platform, with 344 entrepreneurs. A correlation analysis has been used in the study. As a result of correlation analyses, there is a significant relationship between entrepreneurial self-efficacy and risk taking propensity, attitude towards entrepreneurial behavior, entrepreneurial intent and emotional intelligence; there is a significant relationship between risk taking propensity and attitude towards entrepreneurial behavior, entrepreneurial intent and emotional intelligence; there is a significant relationship between attitude towards entrepreneurial behavior and entrepreneurial intent and emotional intelligence; it was also determined that there was a significant relationship between entrepreneurial intent and emotional intelligence.

The existence of a positive and significant correlation between the concept in question is also supported by the studies in the literature. In the next stage of the study, it is considered to expand the study based on the data obtained. Among these concepts, it is planned to develop and test hypotheses based on past studies.

The study focused on the personal and cognitive factors of startups that impact entrepreneurial intent. Also, cognitive factors such as attitudes towards entrepreneurial behavior were investigated together to determine the influential factors on both intent and attitude, which contributed to understanding the entrepreneurial process better; and distinguished the study. Another unique contribution of the study is the fact that it involved startups in technoparks since it is the first study conducted with startups. 


\section{Giriş}

Rekabetçi bir çevre, globalizm, hızla değişen teknolojik uygulamalar ve kapitalist ekonominin varlığı örgütlerin bu düzende ayakta kalabilmeleri için birtakım önlemler almalarını gerekli kılmaktadır. Bu çevrede risk alabilen, girişimci faaliyetlerde bulunabilen örgütler varlıklarını daha başarılı bir şekilde sürdürebilirler. Girişimci bir çevrede örgütsel başarıyı ve performansı arttırmak, örgüt çalışanlarının öz yeterliliklerinin yüksek olmasına bağlıdır. Bireylerin yapmış oldukları işle ilgili kendi başarılarına ve kapasitelerine olan inançları, aynı zamanda başkalarının duygu ve davranışlarını anlayabilen ve ona göre davranabilen kişiler olmaları, girişimci faaliyette bulunabilmeleri, örgütü başarıya taşıyabilmesi açısından kişiye avantaj sağlamaktadır. Artık günümüzde insanlar başkasının rüyası için çalışmak yerine, kendi hayallerinin peşinden koşmayı tercih etmekte ve girişimci olmaktadırlar. Kendine güvenen, başarısına inanan, kendinin ve diğer insanların duygularını doğru anlayıp tanımlayabilen ve bu doğrultuda doğru davranışlar sergileyebilen, kısacası duygusal zekası ve öz yeterliliği yüksek olan bireyler, girişimcilik yolculuğunda daha avantajlı durumdadırlar. Alan yazında girişimci faaliyeti ve niyeti etkileyen en önemli faktörlerden biri olarak kabul edilen risk alma eğiliminin yüksek olması, girişimciliğe giden yolda girişimciye pozitif yönde oldukça önemli katkılar sağlayan diğer bir faktördür. Risk alma eğilimi yüksek olan bireylerin düşük olan bireylere kıyasla girişimcilik faaliyetinde bulunma olasılıklarının daha yüksek olduğu, girişimcilik denildiği zaman risk kavramının öncelikli olarak akla gelen bir kavram olduğu, günümüze kadar yapılmış olan çok sayıda ampirik araştırma ile de desteklenmektedir. Girişimcilik faaliyetleri ekonomiye güç kazandırmakta bir nevi lokomotif işlevi görmektedir; girişimciliğin kişisel, örgütsel, toplumsal ekonomik ve sosyolojik olarak sağladığı faydalar da göz ard1 edilemez. Son dönemlerde yeni kurulan girişimlerin sayısında ciddi oranda artış gözlenmekte; girişimciliğe giden yolda girişimcilere destek sağlayan gerek üniversiteler bünyesinde kurulan gerekse bağımsız olarak faaliyet gösteren teknoparklar, kuluçka merkezleri, diğer taraftan melek yatırımcılar, devlet destekleri ve mikro krediler de giderek önem kazanmaktadır.

Girişimcilik kavramının tarihsel sürecine bakıldığında, çok eski bir geçmişe sahip olmadığı görülür. Girişimcilik, sanayi devrimiyle birlikte önem kazanmaya başlamış aynı zamanda ekonominin yeniden inşa edilmesine ciddi anlamda katkılar sağlamıştır. Bilgi çağı ile birlikte girişimcilik toplum tarafından kabul gören psikolojik, sosyolojik, ekonomik, teknolojik perspektiflere sahip, çok yönlü bir çalışma alanı olmuştur. Girişimcilik faaliyetlerinde ki artış son yıllarda araştırmacıları ağırlıklı olarak bu konuda araştırma yapmaya yönlendirmiştir. Evrensel olarak girişimcilik, girişimde bulunmak olarak tanımlanırken geniş anlamda ele alındığında bireysel, örgütsel, toplumsal ve uluslararası alanda hem sosyolojik hem kültürel hem de ekonomik fayda sağlayan bir kavramdır (Debarliev vd., 2015: 143). Girişimcilikle ilgili yenilik ve risk alma isteklerinin dünyanın değişiminde taşıdığı öneme vurgu yaparak söz konusu ilginin artarak süreceğini ifade etmiştir.

Gelişen dünya düzeninde girişimciliğe olan ilginin artması ve neden insanların bazıları kurumsal bir yapı içinde çalışmayı tercih ederken, bazıları ise girişimciliği tercih etmektedir sorusu araştırmacıları girişimciliğe etki eden faktörleri araştırmaya yönlendirmiştir. Girişimciliğe yönelik niyet ise girişimci davranışın en önemli öncülü olarak kabul edilmektedir. $\mathrm{Bu}$ çalışmada öncelikle girişimcilik, girişimcilik niyeti, girişimcilik niyeti üzerinde etkili olan kişisel faktörlerden duygusal zeka, risk alma eğilimi, girişimci öz yeterlilik ve bilişsel faktörlerden girişimci davranışa yönelik tutum kavramlarına ilişkin literatür taraması ve söz konusu kavramların girişimcilik niyeti ile olan ilişkisi ele alınmış, bu konuda alan yazında yer alan çalışmalara yer verilmiştir. Analiz aşamasında ise teknopark bünyesinde faaliyet gösteren, yeni kurulmuş (maksimum 5 yıllık) veya kurulmakta olan start up girişimlerin kurucuları ile nicel bir çalışma yapılmıştır. Yapılan korelasyon analizi sonucunda start up girişimcilerde 
girişimcilik niyeti üzerinde etkili olan kişisel faktörler (duygusal zeka, risk alma eğilimi, girişimci öz yeterlilik), bilişsel faktör olan girişimci davranışa yönelik tutum ve girişimcilik niyeti arasındaki ilişkilerin yönü ve derecesi tespit edilerek, alan yazındaki mevcut çalışmaların bulguları çerçevesinde bir değerlendirme yapılmıştır.

\section{Teorik Altyapı}

\subsection{Girişimcilik ve Girişimcilik Niyeti}

Girişimcilik; bilimsel anlamda ilk defa Fransız bilim insanlarınca ele alınmış, Fransız yazar J.B. Say tarafından kullanılarak literatüre girmiştir. J.B.Say'dan sonra İrlandalı ekonomist Cantillon da girişimcilik kelimesini eserlerinde sık olarak kullanmıştır (Top, 2012:4). İrlandalı ekonomist Cantillon girişimciliği, "Girişimcilik, henüz belirlenmemiş bir fiyat ile üretim girdilerini satın almak ve üretmektir” ş̧eklinde tanımlamıştır (Yüksel vd., 2015:146). Say’a göre girişimci, ekonomik kaynakların düşük verim sağlayan alanlardan yüksek verim sağlayan alanlara doğru yönünü değiştirerek ekonomide değer yaratan kişidir (Er, 2012:22). Schumpeter yazmış olduğu "Kapitalizm, Sosyalizm ve Demokrasi" isimli eserinde sadece kapitalizmin mevcut yapıyı nasıl yönettiğini değil, aynı zamanda yapıyı nasıl meydana getirdiğini ve yıktığını anlatmıştır. Schumpeter tarafından "yıkıcı yenilik" olarak ifade edilen bu süreç ekonomik gelişmenin özünü oluşturmaktadır (Hebert ve Link, 1989:44).

Son zamanlarda ülkelerin gelişmişlik düzeyleri girişimcilikle ilgili kriterler tarafından belirlenmektedir. Ülke refahı ve büyümesi yani diğer bir ifadeyle ülkelerin gelişmeleri bireylerin kendi işlerini kurma konusunda sahip oldukları niyetin gücü ile ölçülmektedir (Autio vd., 1997). Bu durum, girişimciliğin en önemli göstergesi olarak kabul edilen girişimcilik niyetinin ve bu konuda yapılan çalışmaların önemini arttırmaktadır. Niyet olgusu duygusal, teknolojik, sosyal ve bilişsel bir alandır, girişimcilik onun üzerine inşa edilmektedir (Top, 2017:5). Kişinin davranışı, kişinin o davranışı yapmak ya da yapmamak yönündeki niyeti tarafından belirlenir (Miranda vd., 2017/a: 114). Bazı araştırmacılar kişisel karakter özellikleri değişkeni ile karşılaştırıldığında kişisel girişimci niyetinin girişimci davranışların öngörülmesinde daha etkin ve daha güçlü bir açıklayıcılığa sahip olduğunu savunmaktadırlar (Peng vd., 2012:95). Diğer taraftan Krueger ve Carsrud (1993), Kolvereid (1996), Van Gelderen vd. (2008)'ne göre girişimcilik niyeti kavramına literatürde seksenlerin son dönemlerinden itibaren değinilmeye başlanmıştır. Niyet kavramı, Lee vd. (2011) tarafından şirketin oluşum sürecinde işe başlamanın ilk adımı olarak dikkate alınmıştır. Krueger ve Brazeal (1994) özellikle davranışların nadir, gözlenmesinin zor olduğu ve öngörülemeyen gecikmelerin söz konusu olduğu durumlarda niyetin, kişisel davranışların en güçlü göstergesi olduğunu belirtmişlerdir. Bununla beraber Krueger vd. (2000); girişimci davranış1 gerçekleştirmek için kişilerin nasıl yoğun bir şekilde hazırlandıkları ve ne kadar bir efor sarfettiklerini de girişimci niyetin bir işareti olarak görmüş; insanlar önemli bir potansiyele sahip olsalar bile, niyetleri konusunda bir eksiklik söz konusu ise, girişimden kaçındıklarını vurgulamışlardır. Bird (1988) ise, girişimci olmak için karar verme durumunda en yakın göstergenin girişimci niyet olarak görüldüğünü ifade etmiştir (Nabi ve Linan, 2013:634; Miranda vd., 2017/b:69). Girişimcilik araştırmaları Krueger vd. (2000)'e göre iki aşama etrafında yapılanmıştır; birincisi kişisel (kişilik, demografik ve bilişsel) özellikler, diğeri de yeni kurulan işletmenin faaliyette bulunduğu çevrenin özellikleridir. Kişilik özellikleri ve demografik özellikler üzerine yoğunlaşan önceki yaklaşım, girişimcilik niyet ve davranışını açıklamada yeteri kadar başarılı olamamıştır. Girişimcilik niyeti, demografik ve kişilik özelliği faktörleri ile kıyaslandığında davranışın en iyi göstergesi olarak bilinir (Sabah, 2016:88). Girişimcilik çalışmalarının yapıldığı ilk dönemlerde kişilik özelliklerine ve durumsal 
değişkenlere odaklı araştırmaların yoğunluğu dikkat çekmektedir (Xu vd., 2016:626). Daha sonraki dönemlerde ise (Carsrud ve Braanback, 2011:10) araştırmacıların dikkatlerini yöneticileri lider ve girişimcilerden ayıran çalışmalara yönelttiklerini; girişimci süreç ve faaliyetlere yoğunlaştıklarını ifade etmişlerdir. Girişimcilik araştırmalarında yaşanan bu süreç; girişimcilik niyetini ön plana çıkarmış, girişimcilik davranışının oluşum sürecinde bilişsel faktörlerin ve girişimcilik niyetinin de önemi artmıştır. Girişimcilik niyeti üzerinde sadece kişilik faktörlerinin etkili olmadığı ve kişilik faktörlerine odaklı olarak yapılan araştırmaların konuyu aydınlatmada yetersiz kaldığı zaman içinde yapılan çalışmalar ile anlaşılmış, çalışmalar zamanla bilişsel faktörlere kaymaya başlamıştır. Alan yazında bilişsel faktörleri dikkate alarak girişimci niyeti açıklamaya çalışan çok sayıda model geliştirilmiş ve bu modelleri esas alan çalışmalar yapılmıştır. Bu modellerde niyet; yeni bir girişim sürecini anlamak için oldukça önem taşıyan anahtar bir faktör olarak nitelendirilmekte, girişimciliğe giden süreçte, girişimcilik davranışının oluşmasında çok etkili bir öncül olarak değerlendirilmektedir. Araştırmada Ajzen (1991)'nin planlı davranış modelinin bir bileşeni olan girişimci davranışa yönelik tutum kavramı bilişsel faktör olarak ele alınmıştır.

\subsection{Risk Alma Eğilimi}

Risk alma eğilimi alan yazında, girişimcilik niyeti üzerinde etkili olan en önemli kişisel faktörlerden birisi olarak ifade edilmiştir, hatta alan yazın incelendiğinde girişimcilik ile birlikte akla ilk gelen kavramın risk kavramı olduğunu ve girişimcilik araştırmalarında en çok konu edilen kavramın da yine riskle ilgili kavramlar olduğunu söylemek mümkündür. Kişilerin beyinlerinde oluşturdukları risk algısı aynı zamanda, risk alma eğilimleri üzerinde de önemli bir etkiye sahiptir. Risk algısı Renn ve Rohman (2000)'a göre, kişilerin maruz kaldıkları yahut maruz kalmaları olası risklere karşı yargılarını ifade etmektedir. Risk alma eğilimi, risk alma ya da riskten kaçınma yönelimini olarak tanımlanabilir. Girişimcilik kavramı daima risk alma eğilimi ile ilişkili bir durumdur; yapılan araştırma sonuçları (Ozaralli ve Rivenburg, 2016: 9) yüksek risk alan kişilerin girişimcilik niyeti düzeylerinin daha güçlü olduğunu göstermektedir. Diğer taraftan ise Zhao vd. (2010) risk eğiliminin diğer girişimcilik özellikleri ile karşılaştırıldığında girişimcilik niyetinin en önemli göstergesi olduğunu bunun yanı sıra girişimcilik performansı ile olan ilişkisinin ise çok önem taşımadığını iddia etmektedirler.

Alan yazında risk ile girişimcilik arasında direk, pozitif ve anlamlı bir ilişkinin varlığına ilişkin sonuçlar elde etmiş olan araştırmalar yoğunluktadır. Risk davranışının incelendiği Cramer vd. (2002)'nin çalışmasının sonucunda girişimci kişilerin ücretli çalışanlar ile kıyaslandığında daha az riskten kaçınma davranışı gösterdikleri, aynı zamanda riskten kaçınma davranışının kişilerin girişimciliğe yönelik cesaretini yok ettiği şeklinde bir bulguya ulaşmışlardır. Lüthje ve Franke (2003) tarafından üniversite öğrencileri üzerinde gerçekleştirilen araştırmada kişilik özelliği olarak risk alma eğilimi ve iç kontrol odağı ele alınmış, bu faktörlerin girişimci davranışa yönelik tutum ve girişimcilik niyeti üzerindeki etkisi inceleme konusu yapılmıştır, sonuç olarak ise kişilik özelliklerinin (risk alma eğilimi ve iç kontrol odağı) girişimci davranışa yönelik tutum üzerinde kuvvetli bir etkiye sahip olduğu, tutum ile de yeni bir girişime başlama niyeti arasında güçlü bir ilişkinin söz konusu olduğu ortaya çıkmıştır.

\subsection{Duygusal Zeka}

Psikoloji literatüründe bilimsel anlamda duygusal zekâ kavramı ilk defa Salovey ve Mayer (1990) tarafından ifade edilmiş, daha sonra ise Goleman (1995)'ın kaleme aldığı 'Duygusal 
Zekâ" isimli kitap ile de popülerlik kazanmıştır (Mortan vd., 2014: 98; Chatterjee ve Kulaklı, 2015:293). Akademik dünyada ise duygusal zekâ ilk kez Salovey ve Mayer (1990) tarafından "kişinin kendisinin ve başkalarının his ve duygularını kontrol edebilmesi, izleyebilmesi; bu duyguları bir birinden ayırabilmesi ve bu bilgilerin başkasının düşünce ve faaliyetlerini anlama konusunda kişiye yol gösterebilmesi yeteneğini içeren bir tür sosyal ve kişisel zekâ" olarak tanımlanmıştır. Son y1llarda duygusal zekânın girişimcilik niyeti üzerindeki etkisi ile ilgili araştırmalar dikkat çekmektedir. Araştırma sonuçlarına göre ise duygusal zekâ ile girişimcilik niyeti arasında pozitif bir ilişki olduğu ortaya çıkmıştır (Zampetakis vd., 2009; Mc Laughlin, 2019; Zakarevičius ve Župerka, 2010; Ahmetoğlu vd., 2011; Uslu, 2015; Timuroğlu ve Akpunar, 2017; Tiwari vd., 2017).

Alan yazında duygusal zekanın girişimci davranışa yönelik tutumu pozitif yönde etkilediği sonucunu elde etmiş araştırmalar mevcuttur. Zampetakis vd. (2009)'nin Yunanlı üniversite öğrencileri üzerinde gerçekleştirdikleri çalışma sonucuna göre duygusal zekâ ile girişimci davranışa yönelik tutum arasında pozitif bir ilişki söz konusudur; Zakarevičius ve Župerka (2010)'nın yine üniversite öğrencileri üzerinde yaptıkları bir başka çalışmanın bulgusu ise duygusal zekânın alt boyutlarının girişimci davranışa yönelik tutum üzerinde pozitif bir etkiye sahip olduğu yönündedir. Konuyla ilgili bir diğer çalışma Tiwari vd. (2017)’nin Hindistan da gerçekleştirdikleri çalışmadır, üniversite öğrencileri üzerinde yapılan araştırma sonuçlarına göre duygusal zekânın girişimci davranışa yönelik tutum üzerinde pozitif bir etkisi mevcuttur.

\subsection{Girişimci Öz Yeterlilik}

Öz yeterlilik kavramı girişimcilik konusunda yapılan çalışmalarda sıklıkla ele alınan ve alan yazında çok sayıda tanımı yapılmış olan bir kavramdır (McLaughlın, 2010: 4; Naktiyok, Karabey ve Güllüce, 2010:422; Şeşen ve Basım, 2012:23). Kavram, Bandura (1997)'nın "Sosyal Öğrenme Teorisi”" nden türetilmiştir. Öz yeterlilik ilk defa, Bandura (1977) tarafından kişinin kendine verilen görevi başarma konusunda sahip olduğu kapasiteye olan inanc1 (Bandura, 1995:2; Şeşen ve Basım, 2012:23) şeklinde ifade edilmiş, daha sonraki yıllarda ise kavram ile ilgili çok sayıda tanım yapılmıştır. Öz yeterlilik, kişinin görevlerini yerine getirme aşamasında ihtiyacı olan faaliyetleri planlama ve uygulama konusunda gerekli olan yeteneklerin kendinde bulunduğuna ilişkin sahip olduğu inancıdır (Bandura, 1997:3). Öz yeterlilik, Wood ve Bandura (1989) tarafından kişinin hayatında meydana gelen olayları kontrol etmek için ihtiyaç duyduğu motivasyon, bilişsel kaynaklar ve davranış tarzlarını harekete geçirme konusunda sahip olduğu yetenekler olarak tanımlanmıştır. Girişimci öz yeterlilik kavramı ise Boyd ve Vozikis (1994) tarafından kişilerin girişimcilik sürecindeki görevlere ilişkin kendilerine duydukları güven, ayrıca Chen vd. (1998) tarafından ise kişinin girişimcilikle ilgili olan rol ve görevleri ifa etme yeteneğine olan inancı şeklinde tanımlanmıştır.

Öz yeterlilik kavramı girişimcilik ve girişimcilik niyeti ile ilgili çok sayıda çalışmaya konu olmuştur, geçmiş yıllarda yapılmış çalışmalar göstermektedir ki, öz yeterlilik girişimci bir faaliyete karar verme noktasında oldukça önem taşıyan bir faktördür. Boyd ve Vozikis (1994); Krueger ve Brazeal (1994); Zhao vd. (2005), girişimci niyet ile ilgili geçmiş çalışmalarında öz yeterliliğin girişimci niyetin gelişiminde kritik bir değişken olduğunu ileri sürmektedirler. McGee vd. (2009), yeterlilik kararının, davranış ve amaca ulaşmayı etkilediğini, girişimci niyetin gücü üzerinde kesin bir etki uyguladığını ve sonuçta niyetlerin faaliyete dönüştüğünü vurgulamıştır. Diğer taraftan Chen vd. (1998) ise, öz yeterlilik ve girişimcilik arasındaki ilişkiyi kariyer seçimi gibi risk ve belirsizlik içeren durumlarda da en iyi şekilde ispatlanmış bir durum olduğunu belirtmişlerdir (Laviolette vd., 2012: 723). Ayrıca Mueller ve Goic (2003), Zhao vd. 
(2005), Florin vd. (2007)'ne göre son araştırmalar desteklemektedir ki kişinin girişimci öz yeterliliğin yetiştirme ve eğitim faaliyetleri ile yükseltilebilir ve bu duruma paralel olarak girişimci faaliyetlerin oranı da artış gösterir (McGee vd., 2009: 965-966).

\subsection{Girişimci Davranışa Yönelik Tutum}

Girişimciliğe giden yolda girişimci davranışa yönelik tutum, bilişsel bir faktör olarak girişimcilik niyeti üzerinde oldukça etkilidir, girişimcilik niyet modellerinde farklı isimler altında ifade edilen tutum, Ajzen (1991)'in Planlı Davranış Modelinde subjektif norm ve algılanan davranışsal kontrol ile beraber girişimcilik niyetine etki eden üç önemli bileşen olarak yer almakta ve konuyla ilgili olarak gerçekleştirilen çalışmalarda ağırlıklı olarak göze çarpmaktadır.

Bir davranışı sergilemeye yönelik olan tutum, o davranışı yapmak için kişinin sahip olduğu isteğin bir algısı olarak tanımlanmıştır (Ajzen, 1991). Bu durum, davranışların sonucunda elde edilen çıktıların kişisel etkisiyle ilgili olarak kişinin sahip olduğu beklenti ve inançlara bağlıdır (Husna vd., 2010:3). Tutum, kişilerin elde edilecek çıktıların pozitif ya da negatif sonuçlarına ilişkin inançlarından ortaya çıkmaktadır. Kişi yeni bir işe başlama ile ilgili ne kadar fazla olumlu çıktıların varlığını algılıyorsa, girişimci davranışa yönelik tutumu da o derece fazla olacaktır aynı zamanda da yeni bir iş kurmak için daha güçlü bir niyet içinde olacaktır (Kibler, 2013:239), yani kısacası diyebiliriz ki davranışa yönelik tutum olumluysa, davranışa yönelik niyet de o kadar güçlüdür (Sabah, 2016:90). Kişisel tutum, Ajzen (1991), Conner vd. (2003)'ne göre insanların söz konusu olan davranışa ilişkin olumlu ya da olumsuz değerlendirmeleri olarak ifade edilir (Nabi ve Linan, 2013:635; Haus vd., 2013:133; Tsai vd., 2016:448; Sabah, 2016:90). Diğer bir deyişle kişisel tutum Krueger vd., (2000) tarafından, bir davranışın kişisel çekiciliği olarak tanımlanmıştır. Ajzen (1991)'e göre kişinin davranışa yönelik olan tutumu kişinin algısı, belirli davranışa yönelik kararları, beklenen sonuçları ve bir çok alanda çıktıların etkisi olarak tanımlanır (Ajzen, 1991, Ariff vd., 2010: 3; Khuong ve An, 2016: 106). Söz konusu çıktılar ise örneğin hayatın kalitesi, kişisel bağlılık, bağımsızlık, stres, işbirliğinin faydaları olarak araştırmalarda ele alınmış (Shapero, 1982) daha sonraki dönemlerde ise Krueser vd. (2000) tarafindan test edilmiştir (Khuong ve An, 2016:106). Ajzen (1991), hedef davranışa yönelik olan niyetin, bu niyetin altında yatan bir grup tutuma bağlı olduğunu dikkate almıştır. Özellikle de, belirli bir faaliyete yönelik olan niyet, hem katılımcıların davranışın kişisel ve sosyal çekiciliğine ilişkin algılarına hem de katılılmcıların söz konusu faaliyeti başarılı bir şekilde gerçekleştirebileceklerine ilişkin algılarına bağlıdır (Ferreira vd., 2012:429). Bazı araştırmacılar (Ajzen ve Fishbein, 1980; Ajzen ve Madden, 1986), davranışlarda geniş aralıklarla meydana gelen büyük değişimleri tutum faktörü ile açıklamak eğilimindedirler. Benzer şekilde çok sayıda araştırmada (Robinson vd., 1991; Kolvereid, 1996; Autio vd., 1997) spesifik tutumların gelecekteki yeni girişimleri anlamaya yönelik taşıdıkları önemin farkındadırlar ve aynı zamanda yaptıkları çalışmalar ile bu durumu kanıtlamışlardır (Lüthje ve Franke, 2003:137).

Alan yazında bilişsel faktörler ile girişimcilik niyeti arasındaki ilişkiyi ele alan çok sayıda çalışmaya rastlamak mümkündür. Konuyla ilgili önceki çalışmalar (Kolvereid, 1996; Krueger vd., 2000; Autio vd., 1997; Van Gelderen vd., 2008) tutum ve davranışa yönelik niyet arasında pozitif bir ilişkinin varlığını gösterir. Autio vd. (1997)'nin çalışması her bir tutumun girişimci niyeti güçlü bir şekilde etkilediğini ölçmüştür. Benzer sonuçlar Kolvereid (1996), Krueger vd. (2000), Soutaris vd. (2006), Gird ve Bagraim (2008)'in çalışmaları sonucunda da elde edilmiştir (Ariff vd., 2010:3). Sonraki yıllarda yapılan Lee vd. (2011)'nin çalışması da girişimciliğe yönelik tutum ve niyet arasında önemli bir ilişki bulmuştur. Girişimci davranışa yönelik 
tutumun girişimcilik niyeti üzerinde pozitif bir etkiye sahip olduğu sonucunu elde eden çalışmaların sayısı ağırlıktadır. Son yıllarda yapılan çalışmalarda benzer sonuçlara ulaşılmış, tutum ve niyet arasında pozitif bir ilişkinin varlığı teyit edilmiştir. Sabah (2016)'ın işletme öğrencileri üzerinde yaptıkları araştırmanın sonucu öz yeterlilik ve tutumun girişimcilik niyeti üzerinde etkili en önemli faktörler olduğu, subjektif normların ise niyet üzerinde daha az bir etkiye sahip olduğu şeklindedir.

\section{METODOLOJI}

\subsection{Araştırmanın Amacı}

Araştırmanın amacı, start up girişimlerde girişimcilik niyetinin ortaya çıkmasında etkili olan kişilik faktörlerinin ve bilişsel faktörlerin birlikte incelenmesi, söz konusu değişkenler arasındaki ilişkinin belirlenmesi ve özellikle girişimciliğe giden yolda bilişsel sürecin ve bilişsel faktörlerin önemine dikkat çekmektir. Bu bağlamda kişilik faktörleri; risk alma eğilimi, duygusal zeka ve girişimci öz yeterlilik çerçevesinde kapsamlı olarak değerlendirilmiş, bilişsel faktörler de, girişimcilik davranışına yönelik tutum kavramı çerçevesinde ele alınarak çalışmaya dahil edilmiştir. Konuyla ilgili alan yazında start up girişimciler ile ilgili bir çalışmaya rastlanmamıştır. Bu bağlamda amaç, daha önce farklı örneklemler ile gerçekleştirilen araştırmalardan elde edilen sonuçları girişimcilik ekosistemi içinde test etmektir.

\subsection{Araştırmanın Örneklemi}

Araştırma evreni olarak İstanbuldaki Teknoparklar, araştırma örneklemi olarak ise İstanbul da bulunan üç adet Teknopark ve bir adet girişimcilik platformu seçilmiştir. Bu teknoparkların seçilme sebebi ise, evreni en iyi şekilde temsil ettikleri düşüncesidir, söz konusu teknoparklar İstanbulun en büyük, en kapsamlı teknoparklarıdır. Çalışmada yeni kurulan işletmeler hedef alınmış, bu bağlamda veriler teknoparkların ön kuluçka, kuluçka ve ileri kuluçka merkezlerinde bulunan kurulma aşamasında olan ya da en fazla beş yaşında olan startup firmalarda ki girişimcilerden toplanmıştır. Araştırmanın örneklemini oluşturan bu teknoparklar; Teknopark İstanbul (Cube Incubation Kuluçka Merkezi), İstanbul Ticaret Odası Bilgiyi Ticarileştirme Merkezi, İstanbul Teknik Üniversitesi Arı Teknokent Çekirdek ve İstanbul Teknik Üniversitesi Ar1 Teknokent Magnet, girişimcilik platformu ise, Startup Grind olarak belirlenmiştir. Araştırmanın analizi, toplam 344 adet soru formu ile gerçekleştirilmiştir. Araştırmaya katılanların \% 72,38'i erkek, \% 27,62'si kadın; \%46,5'i 18-26 yaş aralığında, \%36,92'si 27-35 yaş aralığında, \%12'si 36-44 yaş aralığında, \%4,07'si 45-53 yaş aralığında, \%0,29'u 54-62 yaş aralığındadır. Örneklemi eğitim özellikleri açısından incelediğimizde ise \%65,41'in üniversite, \%4,07'nin yüksekokul, \%2,33'ün lise mezunu, \%27,9'un ise lisansüstü eğitime (yüksek lisans veya doktora) sahip olduğunu görmekteyiz. Araştırmaya katılan girişimcilerin \%48,26's1 yazilım ve enformasyon, \%11,92'i bilgisayar ve elektronik, \%7,852'i ise üretim alanında faaliyet göstermekte, diğer alanda faaliyet gösterenlerin oranı ise $\% 13,08$ 'dir. Girişimlerin $\% 48,84^{\prime}$ ü kuruluş aşamasında, $\% 51,16$ 'lık oran ise son 5 yıl içinde kurulmuş olan girişimlerden meydana gelmektedir. Girişimcilik rütbesi açısından araştırma sonuçları değerlendirildiğinde, araştırmaya katılanların \%55,52'sinin geçmişte bir girişimcilik deneyimi yok iken, \%41,90'ının ise girişimcilik deneyimi bulunmaktadır, aynı zamanda girişimcilerin \%68,90'ının aile geçmişlerinde girişimcilik faaliyeti yoktur, \%30,81'inin aileleri de kendileri gibi geçmişte bir girişimcilik faaliyetinde bulunmuşlardır. 
Tablo 1: Demografik Veriler

\begin{tabular}{|c|c|c|}
\hline Cinsiyet & $\begin{array}{l}\text { Kadın } \\
\text { Erkek }\end{array}$ & $\begin{array}{l}\% 27,62 \\
\% 72,38\end{array}$ \\
\hline \multirow{5}{*}{ Yaş } & $18-26$ & $\% 46,5$ \\
\hline & $27-35$ & $\% 36,92$ \\
\hline & $36-44$ & $\% 12$ \\
\hline & $45-53$ & $\% 4,07$ \\
\hline & $54-62$ & $\% 0,29$ \\
\hline \multirow{4}{*}{ Eğitim Durumu } & Lise & $\% 2,33$ \\
\hline & Yüksekokul & $\% 4,07$ \\
\hline & Üniversite & $\% 65,4$ \\
\hline & Lisansüstü & $\% 27,99$ \\
\hline \multirow{4}{*}{ Sektör } & Yazilım ve Enformasyon & $\% 48,26$ \\
\hline & Bilgisayar ve Elektronik & $\% 11,92$ \\
\hline & Üretim & $\% 7,852$ \\
\hline & Diğer & \%13,08 \\
\hline \multirow{2}{*}{ Şirket Yaşı } & Kurulma Aşamasında & $\% 48,84$ \\
\hline & Yeni Kurulmuş (Son 5 Y1l İçinde) & $\% 51,16$ \\
\hline \multirow{2}{*}{ Girişimcilik Rütbesi } & Geçmişte Girişimcilik Faaliyeti Var & $\% 41,90$ \\
\hline & Geçmişte Girişimcilik Faaliyeti Yok & $\% 55,52$ \\
\hline \multirow{2}{*}{ Ailenin Girişimcilik Rütbesi } & Ailede Girişimci Var & $\% 30,81$ \\
\hline & Ailede Girişimci Yok & \%68,90 \\
\hline
\end{tabular}

\subsection{Araştırmada Kullanılan Ölçekler}

Duygusal Zekâ Ölçeği, Carson vd. (2000) tarafindan geliştirilerek Türkçe'ye Aslan (2013) tarafindan uyarlanan ve 20 maddeden oluşan "Duygusal Zekâ Ölçeği” kullanılmıştır. Ölçek 5 boyuttan (empati, ruh halini ayarlama, kişilerarası ilişkiler, iç motivasyona sahip olma, kendini bilme) ve 20 alt boyuttan oluşan 20 madde ile temsil edilmektedir. Ölçek araştırmada, Aslan (2013) tarafından Türkçeye çevirisi yapılmış olan formatıyla kullanılmıştır.

Girişimci Öz Yeterlilik Ölçeği, DeNoble vd. (1999) ve Kickul ve D’Intino (2005) tarafindan geliştirilen, 6 boyut içeren ve 35 maddeden (Türkçe geçerlilik çalışmasında 7. ve 9 . soruların hiçbir faktöre ait olmadığı sonucuna ulaşılmış ve hesaplamalar 33 soru üzerinden yapılmıştır) oluşan (Başol vd., 2011:13), Türkçe geçerliliği ise Naktiyok vd. (2010) tarafindan gerçekleş̧irilen bir ölçektir. Girişimci öz yeterlilik ölçeği boyutları ise şu şekildedir; temel amacı tanımlamak, beklenmedik zorluklarla baş etmek, yenilikçi bir çevre oluşturmak, yeni ürün ve pazar fırsatları geliştirmek, yatırımcılarla ilişsi başlatmak, temel insan kaynaklarını belirlemek.

Risk Alma Eğilimi Ölçeği, Hisrich ve Peters (2002)'den tercüme edilerek, Alpkan vd. (2002) ile Ören ve Biçkes (2011) tarafindan kullanılan "Risk Alma Eğilimi Ölçeğì" kullanılmıştır, ölçek tek boyutludur ve 6 maddeden oluşmaktadır.

Girişimci Davranışa Yönelik Tutum ve Girişimcilik Niyeti Ölçeği, Liñán ve Chen (2009) tarfından geliştirilmiş olan ölçek kullanılmıştır, girişimci davranışa yönelik tutum ölçeği tek boyut ve 5 maddeden, girişimcilik niyeti ölçeği ise tek boyut ve 6 maddeden oluşmaktadır. Girişimcilik niyeti ölçeği ise Şeşen ve Basım (2012) tarafından Türkçeye çevirisi yapılmış olan formatıyla araştırmada kullanılmıştır. 


\subsection{Veri Analizi ve Sonuçları}

Bu bölümde, araştırmada kullanılan ölçeklere ait yapı geçerliliğini test etmek için kullanılan faktör analizi, ölçek alt boyutlarının kendi aralarında tutarlı olup olmadıklarını ölçmek için kullanılan güvenilirlik analizi (Cronbach Alfa Katsayısı), değişkenler arasındaki ilişkinin hem yönünü hem de derecesini görebilmek için kullanılan korelasyon analizi sonuçlarına ve ayrıca tanımlayıcı istatistiklere yer verilmiştir.

\subsubsection{Doğrulayıcı Faktör Analizi}

Analiz sonucu; duygusal zekâ ölçeğinin faktör yükleri empati boyutu için 0,60 ile 0,85 arasında, ruh halini ayarlama boyutu için 0,52 ile 0,8 arasında, kişilerarası ilişkiler boyutu için 0,47 ile 0,98 arasında, iç motivasyona sahip olma boyutu için 0,73 ile 0,81 arasında, kendini bilme boyutu için ise 0,44 ve 0,94 olarak elde edilmiştir. İç motivasyona sahip olma boyutunun maddesi olan DZ 17 faktör yükü düşük çıktığı içi analizden çıkarılmıştır. DFA sonucu girişimci öz yeterlilik ölçeğinin faktör yükleri temel amacı tanımlama boyutu için 0,52 ile 0,68 arasında, beklenmedik zorluklarla baş etme boyutu için 0,51 ile 0,72 arasında, yenilikçi bir çevre oluşturma boyutu için 0,43 ile 0,85 arasında, yeni ürün ve pazar firsatlarını geliştirme boyutu için 0,48 ile 0,75 arasında, yatırımcılarla ilişsi başlatma boyutu için 0,66 ile 0,82 arasında, temel insan kaynaklarını belirleme boyutu için ise 0,48 ile 0,77 arasında elde edilmiştir. Risk alma eğilimi ölçeğinin DFA sonucu faktör yükleri 0,54 ile 0,66 arasında elde edilmiş, ölçeğin RA2 ve RA3 maddeleri faktör yükleri düşük çıktığı için analizden çıkarılmıştır. DFA sonucu girişimci davranışa yönelik tutum ölçeğinin faktör yükleri 0,70 ile 0,84 arasında, girişimcilik niyeti ölçeğinin faktör yükleri ise 0,42 ile 0,91 arasında elde edilmiştir. Araştırmada kullanılan tüm ölçeklere ait soruların ve boyutların faktör yük değerlerinin 0,45 'den yüksek olması ölçeklerin yapısal geçerliliğini ortaya koymaktadır. DFA sonucunda ölçeklerin kabul edilebilir uyum iyiliği kriterlerini sağladığı bulgusuna ulaşılmıştır, DFA sonuçlarının veri seti ile uyumlu olduğu belirlenmiştir. DFA uyum iyiliği değerlerine ise aşağıdaki tabloda yer verilmiştir.

Tablo 2: DFA Uyum İyiliği Değerleri

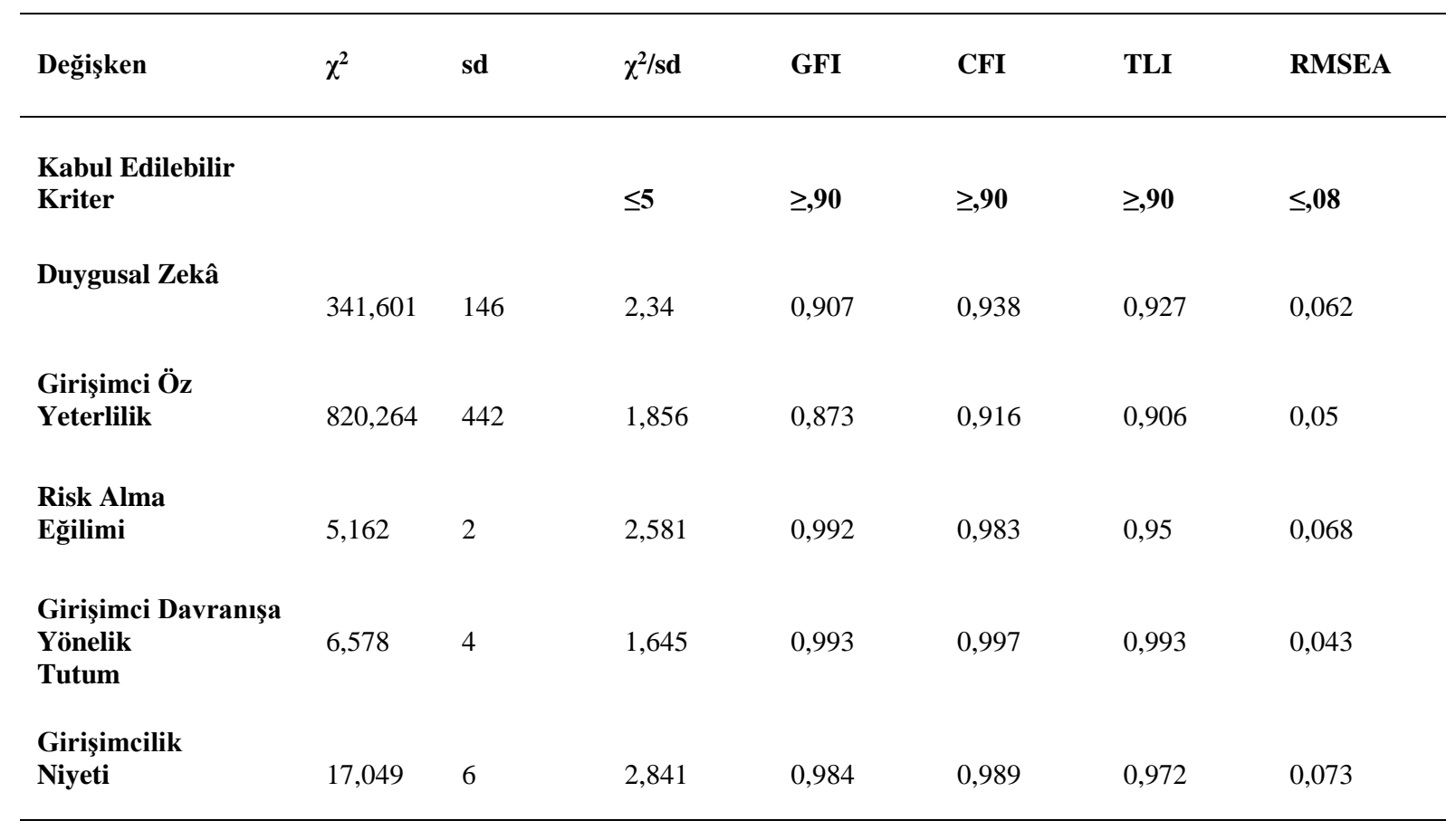




\subsubsection{Güvenilirlik ve Korelasyon Analizi}

Yapılan analiz sonucunda risk alma ölçeğinin alfa katsayısı 0,667 olarak elde edildiğinden ölçeğin orta derecede güvenilir olduğu tespit edilmiş, duygusal zekâ ölçeğinin alfa katsayısı 0,786 olarak elde edildiğinden ölçeğin güvenilir olduğu belirlenmiş, girişimci öz yeterlilik ölçeğinin alfa katsayısı 0,924 , girişimci davranışa yönelik tutum ölçeğinin katsayısı 0,885 ve girişimcilik niyeti ölçeğinin alfa katsayısı ise 0,836 olarak bulunduğu, bu üç ölçeğin de alfa katsayıları 0,80'in üzerinde elde edildiğinden dolayı söz konusu ölçeklerin yüksek güvenilirliğe sahip oldukları bulgusuna ulaşılmıştır. Değişkenler arası ilişkinin yönünü ve derecesini tespit etmek amacıyla yapılan korelasyon analizi sonucu girişimci öz yeterlilik ile risk alma, girişimci davranışa yönelik tutum, girişimcilik niyeti ve duygusal zeka arasında 0,01 anlamlılık düzeyinde anlamlı bir ilişki olduğu; risk alma ile girişimci davranışa yönelik tutum, girişimcilik niyeti ve duygusal zeka arasında 0,01 anlamlılık düzeyinde anlamlı bir ilişki olduğu; girişimci davranışa yönelik tutum ile girişimcilik niyeti ve duygusal zeka arasında 0,01 anlamlılık düzeyinde anlamlı bir ilişki olduğu; girişimcilik niyeti ile duygusal zeka arasında da 0,01 anlamlılık düzeyinde anlamlı bir ilişki olduğu tespit edilmiştir. Güvenilirlik ve korelasyon analizi sonuçlarına ilişkin tablo aşağıdadır.

Tablo 3: Güvenilirlik ve Korelasyon Analizi

\begin{tabular}{|c|c|c|c|c|c|c|c|}
\hline & Ortalama & $\begin{array}{l}\text { Standart } \\
\text { Sapma }\end{array}$ & $\begin{array}{l}\text { Girişimci } \\
\text { Öz } \\
\text { Yeterlilik }\end{array}$ & $\begin{array}{l}\text { Risk Alma } \\
\text { Eğilimi }\end{array}$ & $\begin{array}{l}\text { Girişimci } \\
\text { Davranışa } \\
\text { Yönelik } \\
\text { Tutum } \\
\end{array}$ & $\begin{array}{l}\text { Girişimcilik } \\
\text { Niyeti }\end{array}$ & $\begin{array}{l}\text { Duygusal } \\
\text { Zekâ }\end{array}$ \\
\hline $\begin{array}{l}\text { Girişimci } \\
\text { Öz Yeterlilik }\end{array}$ & 4,0229 & 44858 & $(, 924)$ & & & & \\
\hline $\begin{array}{l}\text { Risk Alma } \\
\text { Eğilimi }\end{array}$ & 4,0988 & ,70326 &, $459^{* *}$ & $(, 667)$ & & & \\
\hline $\begin{array}{l}\text { Girişimci } \\
\text { Davranışa } \\
\text { Yönelik Tutum }\end{array}$ & 4,3459 & 64685 &, $503^{* *}$ &, $355^{* *}$ & (,885) & & \\
\hline Girişimcilik Niyeti & 4,2471 & 63352 &, $474^{* *}$ &, $322^{* *}$ &, $737^{* * *}$ & $(, 836)$ & \\
\hline $\begin{array}{l}\text { Duygusal } \\
\text { Zekâa }\end{array}$ & 3,7742 & ,43107 &, $581^{* *}$ &, $381^{* *}$ &, $335^{* *}$ &, $284^{* *}$ & $(, 786)$ \\
\hline
\end{tabular}

\subsubsection{Tanımlayıcı İstatistikler}

Bu bölümde veri setinin dağılımı ve değişimini değerlendirmek amacıyla frekans dağılımları ölçekler bazında ele alınmış, her bir ölçeğe ilişkin sonuçlara aşağıda yer verilmiştir. 
Tablo 4: Girişimci Öz Yeterlilik Ölçeği Sorularına İlişkin Temel İstatistikler

\begin{tabular}{|c|c|c|c|c|c|c|}
\hline \multirow{2}{*}{$\begin{array}{l}\text { SORULAR } \\
\text { TEMEL AMACI TANIMLAMAK }\end{array}$} & \multicolumn{6}{|c|}{ TEMEL İSTATİSTÍKLER } \\
\hline & Mì & MAK & ORT & SS & KURT & SKEW \\
\hline 17. Örgütün vizyonunu ve değerlerini tereddüt etmeden ifade edebilirim. & 1 & 5 & 4,16 & 0,77 & 0,48 & $-0,73$ \\
\hline $\begin{array}{l}\text { 18. Şirketin vizyon ve değerlerini sahiplenmeleri için diğer kişilere ilham } \\
\text { verebilirim. }\end{array}$ & 2 & 5 & 4,31 & 0,70 & 1,02 & $-0,91$ \\
\hline 19. Fırsatları kovalamak için gereken faaliyetleri belirleyebilirim. & 1 & 5 & 4,18 & 0,71 & 1,13 & $-0,76$ \\
\hline $\begin{array}{l}\text { 20. Vizyonumu takip etmek için bana katılmaları konusunda diğer } \\
\text { kişileri ikna edebilirim. }\end{array}$ & 1 & 5 & 4,19 & 0,75 & 1,68 & $-0,96$ \\
\hline 21. Benim bakış açımı kabul etmeleri için diğer kişileri ikna edebilirim. & 1 & 5 & 4,08 & 0,81 & 0,58 & $-0,78$ \\
\hline $\begin{array}{l}\text { 22. Benim lehime olacak çıktıları elde edebilmek için müzakere sürecini } \\
\text { yönetebilirim. }\end{array}$ & 1 & 5 & 3,94 & 0,82 & 0,29 & $-0,58$ \\
\hline BEKLENMEDİK ZORLUKLARLA BAŞ ETMEK & MíN & MAK & ORT & SS & KURT & SKEW \\
\hline $\begin{array}{l}\text { 23. Sürekli çatışma, stres ve bask1 ile karşılaşılan ortamlarda verimli } \\
\text { olarak çalışabilirim. }\end{array}$ & 1 & 5 & 3,46 & 1,19 & $-0,72$ & $-0,45$ \\
\hline 24. İş koşullarındaki beklenmedik değişiklikleri tolere edebilirim. & 1 & 5 & 3,89 & 0,85 & 0,70 & $-0,73$ \\
\hline 25. Zorluklar karşısında ısrarcı olabilirim. & 1 & 5 & 4,13 & 0,77 & 0,58 & $-0,73$ \\
\hline $\begin{array}{l}\text { 26. Karşı çıkanların olumsuz geri bildirimlerine ve engellere rağmen } \\
\text { iyimser bakış açımı sürdürebilirim }\end{array}$ & 1 & 5 & 3,97 & 0,84 & 0,70 & $-0,75$ \\
\hline 27. Belirsizlikleri tolere edebilirim. & 1 & 5 & 3,78 & 0,99 & 0,19 & $-0,75$ \\
\hline $\begin{array}{l}\text { 28. Beklenmedik değişiklik ve başarısızlıklara hızlı bir şekilde tepki } \\
\text { gösterebilirim. }\end{array}$ & 1 & 5 & 3,80 & 0,89 & 0,30 & $-0,59$ \\
\hline YENİLİKÇİ BİR ÇEVRE OLUŞTURMAK & MìN & MAX & ORT & SS & KURT & SKEW \\
\hline $\begin{array}{l}\text { 9. İnsanların daha fazla kendi kendilerinin patronu olmalarına izin veren } \\
\text { bir iş ortamı yaratabilirim }\end{array}$ & 1 & 5 & 4,02 & 0,94 & 0,21 & $-0,80$ \\
\hline $\begin{array}{l}\text { 10. Yeni bir şey denemek için insanları destekleyen bir iş çevresi } \\
\text { geliştirebilirim. }\end{array}$ & 1 & 5 & 4,21 & 0,78 & 0,70 & $-0,86$ \\
\hline $\begin{array}{l}\text { 11. Çıktıları dikkate almaksızın kendi idealleri ve kararları için inisiyatif } \\
\text { ve sorumluluk alma konusunda insanları destekleyebilirim. }\end{array}$ & 1 & 5 & 4,00 & 0,96 & 0,25 & $-0,87$ \\
\hline 12. Diğer kişilerle ortaklık ve ittifak ilişkisi oluşturabilirim. & 1 & 5 & 4,20 & 0,78 & 2,26 & $-1,18$ \\
\hline 13. İnteraktif (etkileşimli) bir iş çevresi geliştirebilirim. & 2 & 5 & 4,27 & 0,70 & $-0,02$ & $-0,64$ \\
\hline YENİ ÜRÜN VE PAZAR FIRSATLARI GELISŞTIRMEK & MíN & MAX & ORT & SS & KURT & SKEW \\
\hline 1. Yeni ürün ve hizmetlere yönelik yeni pazar fırsatlarını görebilirim. & 1 & 5 & 3,89 & 0,88 & $-0,07$ & $-0,54$ \\
\hline 2. Mevcut ürünleri geliştirmek için yeni yollar keşfedebilirim. & 2 & 5 & 4,17 & 0,75 & 0,74 & $-0,83$ \\
\hline 3. Potansiyel büyümeye yönelik yeni alanlar tanımlayabilirim. & 2 & 5 & 4,04 & 0,75 & 0,08 & $-0,52$ \\
\hline 4. Mevcut problemleri çözecek ürünler tasarlayabilirim. & 1 & 5 & 4,12 & 0,81 & 0,55 & $-0,81$ \\
\hline $\begin{array}{l}\text { 5. Müşterilerin tatmin edilmemiş ihtiyaçlarını karşılayacak ürünler } \\
\text { oluşturabilirim. }\end{array}$ & 1 & 5 & 3,96 & 0,83 & 0,03 & $-0,57$ \\
\hline 6. Yeni geliştirilen ürünleri zamanında pazara sunabilirim. & 1 & 5 & 3,62 & 0,81 & $-0,15$ & $-0,11$ \\
\hline $\begin{array}{l}\text { 7. İş firsatlarının avantajlarından yararlanmak için çabucak harekete } \\
\text { geçebilirim. }\end{array}$ & 1 & 5 & 3,80 & 0,98 & 0,91 & $-0,45$ \\
\hline 8. Yeni fikir ve ürünler oluşturabilirim. & 1 & 5 & 4,27 & 0,73 & 1,14 & $-0,92$ \\
\hline
\end{tabular}


Tablo 4 (Devamı): Girişimci Öz Yeterlilik Ölçeği Sorularına İlişkin Temel İstatistikler

\begin{tabular}{|l|c|c|c|c|c|c|}
\hline YATIRIMCILARLA İLIŞKI BAŞLATMAK & MIN & MAX & ORT & SS & KURT & SKEW \\
\hline $\begin{array}{l}\text { 14. Potansiyel yatırımcılar ile uygun bir ilişki geliştirebilir ve bu ilişkiyi } \\
\text { sürdürebilirim. }\end{array}$ & 1 & 5 & 4,02 & 0,78 & 0,42 & $-0,63$ \\
\hline $\begin{array}{l}\text { 15. Sermaye kaynaklarıyla ilişkisi olan anahtar konumdaki kişiler ile } \\
\text { ilişki geliştirebilirim. }\end{array}$ & 1 & 5 & 3,94 & 0,83 & 0,27 & $-0,60$ \\
\hline 16. Yatırımları fonlamak için potansiyel kaynakları belirleyebilirim. & 1 & 5 & 3,77 & 0,89 & 0,22 & $-0,51$ \\
\hline TEMEL İNSAN KAYNAKLARINI BELİRLEMEK & MíN & MAX & ORT & SS & KURT & SKEW \\
\hline 29. Anahtar konumdaki çalışanları işe alabilir ve onları eğitebilirim. & 1 & 5 & 4,11 & 0,81 & 0,44 & $-0,72$ \\
\hline 30. Teknik ekibi yedeklemek için alternatif planlar oluşturabilirim. & 1 & 5 & 4,00 & 0,83 & 0,48 & $-0,66$ \\
\hline 31.Yönetim takımlarını belirleyebilirim ve oluşturabilirim. & 1 & 5 & 4,07 & 0,81 & 0,33 & $-0,69$ \\
\hline 32. Diğer kişilerin uzmanlıklarından faydalanabilirim. & 1 & 5 & 4,42 & 0,67 & 2,08 & $-1,15$ \\
\hline $\begin{array}{l}\text { 33. Kişilerin özel ve iş hayatı arasındaki kaçınılmaz olan çatışmaya } \\
\text { rağmen işin taleplerine odaklanabilirim. }\end{array}$ & 1 & 5 & 3,99 & 0,80 & 0,97 & $-0,76$ \\
\hline
\end{tabular}

Tablo 5: Risk Alma Eğilimi Ölçeği Sorularına İlişkin Temel İstatistikler

\begin{tabular}{|l|c|c|c|c|c|c|}
\hline \multicolumn{1}{|c|}{ SORULAR } & \multicolumn{5}{c|}{ TEMEL İSTATISTIKLER } \\
\cline { 2 - 7 } & MíN & MAK & ORT & SS & KURT & SKEW \\
\hline 1. Korkunca korkunun üstüne giderim. & 1 & 5 & 3,97 & 0,92 & 0,30 & $-0,77$ \\
\hline 4. Son altı ayda bazı riskler aldım. & 1 & 5 & 4,34 & 0,85 & 1,81 & $-1,41$ \\
\hline 5. Hiç tanımadı̆ı̆ birine gidip sohbete başlayabilirim. & 1 & 5 & 4,19 & 1,03 & 0,90 & $-1,26$ \\
\hline 6. Kasıtlı olarak hiç bilmediğim bir yola sapabilirim. & 1 & 5 & 3,89 & 1,15 & $-0,08$ & $-0,87$ \\
\hline
\end{tabular}

Tablo 6: Girişimci Davranışa Yönelik Tutum Ölçeği Sorularına İlişkin Temel İstatistikler

\begin{tabular}{|l|c|c|c|c|c|c|}
\hline \multicolumn{1}{|c|}{ SORULAR } & \multicolumn{5}{c|}{ TEMEL ISTATISTIKLER } \\
\cline { 2 - 7 } & MIN & MAK & ORT & SS & KURT & SKEW \\
\hline 1. Girişimci olmak bana göre, avantaj anlamına gelir. & 1 & 5 & 4,30 & 0,76 & 0,47 & $-0,88$ \\
\hline 2. Girişimci olarak kariyer yapmak benim için caziptir. & 1 & 5 & 4,34 & 0,74 & 0,92 & $-0,98$ \\
\hline 3. Fırsatlarım ve kaynaklarım olursa, yeni bir şirket kurmak isterim. & 1 & 5 & 4,37 & 0,83 & 2,57 & $-1,52$ \\
\hline 4. Girişimci olmak benim için büyük ölçüde tatmine yol açar. & 1 & 5 & 4,38 & 0,75 & 1,42 & $-1,18$ \\
\hline 5. Çok çeşitli seçenekler arasından, girişimci olmayı tercih ederim. & 1 & 5 & 4,34 & 0,82 & 1,26 & $-1,20$ \\
\hline
\end{tabular}


Tablo 7: Girişimcilik Niyeti Ölçeği Sorularına İlişkin Temel İstatistikler

\begin{tabular}{|l|c|c|c|c|c|c|}
\hline \multicolumn{1}{|c|}{ SORULAR } & \multicolumn{5}{|c|}{ TEMEL ISTATISTIKLER } \\
\cline { 2 - 7 } & MİN & MAK & ORT & SS & KURT & SKEW \\
\hline 1. Bir girişimci olarak her şeyi yapmaya hazırım. & 1 & 5 & 3,82 & 1,06 & 0,10 & $-0,79$ \\
\hline 2. Profesyonel olarak hedefim, bir girişimci olmaktır. & 1 & 5 & 4,08 & 0,95 & 0,61 & $-0,96$ \\
\hline 3. Kendi işimi kurmak ve sürdürmek için her türlü çabayı gösterdim. & 1 & 5 & 4,32 & 0,81 & 2,34 & $-1,35$ \\
\hline 4. Bir iş kurma konusunda kararlıyım. & 1 & 5 & 4,38 & 0,71 & 1,20 & $-1,05$ \\
\hline 5. Ciddi anlamda kendi işimi kurmayı düşündüm. & 1 & 5 & 4,49 & 0,72 & 3,70 & $-1,66$ \\
\hline 6. Kendi işimi kurma konusunda ciddi niyetlerim vardı. & 1 & 5 & 4,39 & 0,83 & 2,16 & $-1,50$ \\
\hline
\end{tabular}

\section{Sonuç}

Araştırmada girişimcilik niyeti üzerinde etkili olan kişisel özellikler (risk alma eğilimi, duygusal zekâ ve girişimci öz yeterlilik), bilişsel bir faktör olan girişimci davranışa yönelik tutum ve girişimcilik niyeti arasında bir ilişki olup olmadığ korelasyon analizi ile söz konusu kavramlar arasındaki ilişkinin yönü ve ilişkisi tespit edilmiştir.

Araştırma sonucunda girişimci öz yeterlilik ile risk alma ĕgilimi arasında 0,01 anlamlılık düzeyinde anlamlı bir ilişki bulunmuştur. Konu ile ilgili alan yazındaki öz yeterlilik ile risk faktörünün birlikte ele alındığı çalışmalar incelendiğinde iki kavram arasında anlamlı bir ilişkinin mevcut olduğunu görmekteyiz. Zhao vd. (2005) yapmış oldukları araştırma ile risk alma eğiliminin girişimcilik niyeti ile olan ilişkisinde öz yeterliliğin araci role sahip olduğunu ortaya koymuşlardır. Zhang ve Cain (2017)'in araştırmalarında ise riskten kaçınma davranışının girişimcilik niyeti üzerindeki etkisinde öz yeterliliğin aracı rolüne değinilmiş, riskten kaçınma davranışının öz yeterliliğin aracı etkisi ile dolaylı olarak girişimcilik niyetini azalttığını belirlemişlerdir.

Araştırma sonucunda girişimci öz yeterlilik ile girişimci davranışa yönelik tutum arasında 0,01 anlamlılık düzeyinde anlamlı bir ilişki bulunmuştur. Alan yazında benzer şekilde Tiwari vd. (2017)'nin çalışma sonucu da öz yeterlilik ile sosyal girişimci tutum arasında önemli ve pozitif bir ilişkinin mevcudiyetini ortaya koymaktadır. Sabah (2016)'ın yapmış olduğu araştırma sonucuna göre öz yeterlilik ve girişimci davranışa yönelik tutum, girişimcilik niyeti üzerinde en etkili olan iki faktördür. Bu araştırmada da söz konusu iki faktör arasında ortaya çıkan pozitif ve anlamlı ilişki önemli ve dikkat çeken bir bulgudur.

Araştırma sonucunda girişimci öz yeterlilik ile girişimcilik niyeti arasında 0,01 anlamlılık düzeyinde anlamlı bir ilişki bulunmuştur. Alan yazında bu iki kavram arasındaki ilişkiyi konu edinen çok sayıda araştırma mevcuttur. Chen vd. (1998) ve DeNoble vd. (1999)'nin öğrenciler üzerinde gerçekleştirmiş oldukları araştırma sonucuna göre girişimci öz yeterlilik ile girişimcilik niyeti arasında pozitif ve anlamlı bir ilişki mevcuttur. Benzer bir şekilde Byabashaija ve diğ. (2010)'nun üniversite öğrencileri ile, Nwankwo vd. (2012)'nin ise k1z öğrenciler ile yapmış oldukları araştırmaların sonuçları da girişimci öz yeterlilik ile girişimcilik niyeti arasında anlamlı bir ilişki olduğunu bulgulamıştır. 
Araştırma sonucunda girişimci öz yeterlilik ile duygusal zekâ arasında 0,01 anlamlılık düzeyinde anlamlı bir ilişki bulunmuştur. Mortan vd. (2014)'nin araştırmasında duygusal zekanın girişimcilik niyeti üzerindeki etkisinde öz yeterliliğin aracı rolüne sahip olduğu şeklinde bir sonuç elde edilmiştir. Aynı zamanda duygusal zekanın iki alt boyutunun (duyguların düzenlenmesi ve duyguların kullanılması) öz yeterliliği pozitif yönde etkilemesi de araştırmanın sonucunda elde edilen önemli diğer bir bulgudur.

Araştırma sonucunda risk alma eğilimi ile girişimci davranışa yönelik tutum arasında 0,01 anlamlılık düzeyinde anlamlı bir ilişki bulunmuştur. Lüthje ve Franke (2003), üniversite öğrencileri ile gerçekleştirdikleri araştırma sonucunda kişilik özelliği olan risk alma eğilimi ile girişimci davranışa yönelik tutum arasında güçlü bir ilişkinin olduğu ortaya çıkmıştır; bu bulgu, araştırma sonucunu destekler mahiyettedir.

Araştırma sonucunda risk alma ĕgilimi ile girişimcilik niyeti arasında 0,01 anlamlılık düzeyinde anlamlı bir ilişki bulunmuştur. Konu ile Lüthje ve Franke (2003), Zhao vd. (2005), Timuroğlu ve Çakır (2014), yapmış oldukları araştırma sonuçlarında da risk alma eğilimi ile girişimcilik niyeti arasında kuvvetli bir ilişki olduğunu ortaya koymuşlardır.

Araştırma sonucunda risk alma eğilimi ile duygusal zekâ arasında 0,01 anlamlılık düzeyinde anlamlı bir iliş̧ki bulunmuştur. Benzer bir şekilde Basım vd. (2008), gerçekleştirmiş oldukları araştırma ile öz yeterlilik algısı ile risk alma davranışı arasında anlamlı bir ilişkinin var olduğunu bulgulamışlardır.

Araştırma sonucunda girişimci davranışa yönelik tutum ile duygusal zekâ arasında 0,01 anlamlılık düzeyinde pozitif bir ilişki bulunmuştur. Alan yazında da bu ilişkinin varlığını destekleyen çalışmalar mevcuttur. Zampetakis vd. (2009)'nin üniversite öğrencileri üzerinde gerçekleştirdikleri araştırma bu alanda oldukça önem taşıyan ve ilk sayılabilecek çalışmalardandır. Araştırmacılar geliştirmiş oldukları modelle duygusal zekâ ile girişimci davranışa yönelik tutum arasında pozitif bir ilişkinin var olduğunu ortaya koymuşlardır. Zakarevičius ve Župerka (2010) ise Zampetekis vd. (2009)'nin modeline bazı eklemeler yaparak geliştirdikleri modelle duygusal zekanın alt boyutları ile girişimci davranışa yönelik tutum arasındaki bir ilişki olduğu sonucuna ulaşmışlardır.

Araştırma sonucunda girişimci davranışa yönelik tutum ile girişimcilik niyeti arasında 0,01 anlamlılık düzeyinde pozitif bir ilişki bulunmuştur. Alan yazında da bu ilişkiyi destekleyen güçlü çalışmalar mevcuttur. Ariff vd. (2010), Ferreira vd. (2012), Feder ve Nitu-Antonie (2017)'nin araştırma sonuçları göstermektedir ki girişimci davranışa yönelik tutum ile girişimcilik niyeti arasında pozitif ve anlamlı bir ilişsi mevcuttur. Araştırma sonucunda elde edilen bulgu da bu çalışmaların bulgularını destekler mahiyettedir.

Araştırma sonucunda duygusal zeka ile girişimcilik niyeti arasında 0,01 anlamlılık düzeyinde pozitif bir ilişki bulunmuştur. Alan yazın incelendiğinde bu iki kavram arasındaki ilişkiyi ortaya koyan araştırmaların var olduğu görülmektedir. Zampetakis vd. (2009), Zakarevičius ve Župerka (2010), Mc Laughlin (2019)'in araştırma sonuçlarına göre duygusal zeka ile girişimcilik niyeti arasında pozitif ve anlamlı bir ilişki mevcuttur. Timuroğlu ve Akpunar (2017)'ın araştırma sonucu duygusal zeka ile girişimcilik niyeti arasında güçlü bir ilişkinin varlığını ortaya koyarken, Tiwari vd. (2017)'nin çalışması duygusal zekanın sosyal girişimciliğe yönelik niyet ile aralarındaki pozitif ve önemli bir ilişkiye dikkat çekmektedir.

Görüldüğü üzere araştırma sonucunda elde edilen bulgular, alan yazında daha önce yapılmış çalışma sonuçlarını destekler niteliktedir. Sözkonusu kavramlar arasındaki pozitif ve anlamlı bir korelasyonun varlığı araştırma sonucu bulgulanmış ve alan yazındaki çalışmalar tarafından da teyit edilmiştir. Çalışmanın bir sonraki aşamasında, elde edilen bu verilere 
dayanarak çalışmanın genişletilmesi düşünülmektedir. Çalışmaya konu teşkil eden kavramlar arasında alan yazındaki geçmiş çalışmalar da esas alınarak geliştirilen hipotezlerin test edilmesi planlanmaktadır. Bu doğrultuda start up girişimcilerde girişimcilik niyeti üzerinde etkili olan faktörlerin analiz edilerek girişimciliğe giden sürecin kapsamlı bir şekilde değerlendirilmesi suretiyle girişimcilik ekosistemine katkı sağlanması hedeflenmektedir.

\section{Kaynakça}

Ahmetoğlu, Leutner. \& Premuzic, C. (2011). EQ-nomics: Understanding the Relationship Between Individual Differences in Trait Emotional Intelligence and Entrepreneurship. Personality and Individual Differences, 5(8), 1028-1033.

Ajzen, I. (1991). The Theory of Planned Behavior. Organizational Behavior and Human Decision Process, 50(2): 179-211.

Alpkan, L., Keskin, H. \& Zehir, C. (2002). Girişimcilik Hisleriyle Girişimcilik Potansiyeli Arasındaki İlişki: Gebze ve Civarındaki Girişimciler Üzerine Bir Saha Araştırması. 21. Yüzyılda KOBİ'ler, Sorunlar, Fırsatlar ve Çözüm Önerileri Sempozyumu. Doğu Akdeniz Üniversitesi, İşletme Fakültesi, Gazimagosa, K.K.T.C, Erişim adresi: http://docplayer.biz.tr/31263390, (01.10.2017).

Ariff, A. H., Bidin, Z., Sharif, Z. and Ahmad, A. (2010). Predicting Entrepreneurship Intention Among Malay University Accounting Students in Malaysia. Unitar-Journal, 6(1). pp. 110.

Aslan, Ş. (2013). Duygusal Zeka Dönüşümcü ve Etkileşimci Liderlik, Konya, Eğitim Yayınevi.

Autio, E., Keeley, R. H., Klofsten, M. and Ulfstedt, T. (1997). Entrepreneurial Intent Among Students: Testing and intent model in Asia, Scandinavia and USA. in Sexton, D.L. and Kasarda, J.D. (Eds), Frontiers of Entrepreneurial Research, Babson College Publications,Wellesley,MA,133-47.Erişimadresi:

https://fusionmx.babson.edu/entrep/fer/papers97/autio/aut1.htm, (07.10.2017).

Bandura, A. (1995). Self-Efficacy in Changing Societies, Cambridge, Cambridge University Press.

Bandura, A. (1997). Self-Efficacy: The Exercise of Control, New York, W. H. Freeman \& Company.

Basım, H. N., Korkmazyürek, H. \& Tokat, A. O. (2008). Çalışanların Özyeterlilik Algılamasının Yenilikçilik ve Risk Alma Üzerine Etkisi: Kamu Sektöründe Bir Araştırma. Selçuk Üniversitesi Sosyal Bilimler Enstitüsü Dergisi, (19). pp. 121-130.

Başol, O., Dursun, S. \& Aytaç, S. (2011). Kişiliğin Girişimcilik Niyeti Üzerine Etkisi: Üniversiteli Gençler Üzerine Bir Uygulama. "IŞ, GÜÇ" Endüstri İlişkileri ve İnsan Kaynakları Dergisi, 13(4), 7-22.

Boyd, N. G., \& Vozikis, G. S. (1994). The Influence of Self-Efficacy on the Development of Entrepreneurial Intentions and Actions. Entrepreneurship: Theory and Practise, 18(4), 6377.

Byabashaija, W., Katono, I. \& Isabalija, R. (2010). The Impact of College Entrepreneurial Education on Entrepreneurial Attitudes and Intention to Start a Business in Uganda. Entrepreneurship in Africa Conference, 1-25, Syracuse, NY, Erişim adresi: https://doi.org/10.1142/S1084946711001768, (07.10.2017).

Carsrud, A. \& Braanback, M. (2011). Entrepreneurial Motivations: What Do We Still Need To Know. Journal of Small Business Management, 49(1), 9-26.

Chatterjee, A. \& Kulakl1, A. (2015). An Empirical Investigation of the Relationship between Emotional Intelligence, Transactional and Transformational Leadership Styles in Banking Sector. Social and Behavioral Sciences, (210), 291-300. 
Chen, C.C., Greene, P. G. \& Crick, A. (1998). Does Entrepreneurial Self-Efficacy Distinguish Entrepreneurs From Managers?. Journal of Business Venturing, (13), 295-316.

Cramer, J., Hartog, J., Jonker, N. \& Praag, C. V. (2002). Low Risk Aversion Encourages the Choice for Entrepreneurship: An Empirical Test of a Truism. Journal of Economic Behavior and Organization, 48(1), 29-36.

Debarliev, S., Iliev, A. J., Bozhinovska, T. and IIieva, V. (2015). Antecedents of Entrepreneurial Intention: Evidence from Republic of Macedonia. BEH- Business and Economic Horizons., 11(3). 143-161.

DeNoble, A., Jung, D. and Ehrlich, S. (1999). Entrepreneurial Self-Efficacy: The Development of a Measure and its Relationship to Entrepreneurial Intentions and Actions. Entrepreneurship Theory and Practice, 18(4), 63-77.

Er, P. H. (2012). Joseph A. Schumpeter's Views On Entrepreneurship And Innovativeness. Saarbrücken: LAP LAMBERT Academic Publishing.

Feder, E.-S. \& Nitu-Antonie, R.-D. (2017). Connecting Gender Identity, Entrepreneurial Training, Role Models and Intentions. International Journal of Gender and Entrepreneurship, 9(1), 87-108.

Ferreira, J. J. M., Raposo, M., Rodrigoes, R.G., Dinis, A. \& Paço, A. (2012). A Model of Entrepreneurial Intention: An Application of the Psychological and Behavioral Approaches. Journal of Small Business and Enterprise Development, 19 (3). pp. 424440.

Haus, I., Steinmetz, H., Isidor, R. and Kabst, R. (2013). “Gender Effects on Entrepreneurial Intention: A Meta-Analytical Structural Equation Model”, International Journal of Gender and Entrepreneurship, 5(2). pp. 130-156.

Hebert, R. F. \& Link, A. N. (1989). "In Search of the Meaning of Entrepreneurship”, Small Business Economics, 1(1), 39-49.

Husna, A., Sharif, Z., Bidin, Z. and Ahmad, A. (2010). "Predicting Entrepreneurship Intention among Malay University Accounting Students in Malaysia”, Unitar E-Journal, 6 (1). pp. $1-10$.

Khuong, M. N. \& An, N. H. (2016). “The Factors Affecting Entrepreneurial Intention of the Students of Vietnam National University- A Mediation Analysis of Perception Toward Entrepreneurship”, Journal of Economics, Business and Management, 4(2), 104-111.

Kibler, E. (2013). "Formation of Entrepreneurial Intentions in a Regional Context", Entrepreneurship \& Regional Development, 25(3-4): 293-323.

Kolvereid, L. (1996). "Prediction of Employment Status Choice Intentions”. Entrepreneurship Theory \& Practice, 21: 47-57.

Krueger, N. F. \& Brazeal, D. V. (1994). "Entrepreneurial Potantial and Potantial Entrepreneurs”, Entrepreneurship Theory and Practise,18(3), 91-104.

Krueger, N. F. \& Carsrud, A. (1993). "Entrepreneurial Intentions: Applying the Theory of Planned Behavior”, Entrepreneurship and Regional Development, 5(4), 315-330.

Krueger, N. F., Reilly, M. D. and Carsrud, A. (2000). Competing Models of Entrepreneurial Intentions. Journal of Business Venturing, 15(5-6). pp. 411-432.

Laviolette, E. M., Lefebvre, M. R. and Brunel, O. (2012). "The Impact of Story Bounds Entrepreneurial Role Models on Self Efficacy and Entrepreneurial Intention”, International Journal of Entrepreneurial Behavior\& Resarch, 18(6). pp. 720-742.

Lee, L., Wong, P. K., Foo, M. D. and Leung, A. (2011). "Entrepreneurial Intentions: The Influence of Organizational and Individual Factors”, Journal of Business Venturing, (26). pp. 124-136. 
Liñán, F. \& Chen, Y.-W. (2009). "Development and Cross-Cultural Application of a Specific Instrument to Measure Entrepreneurial Intentions”, Entrepreneurship Theory and Practise, 33(3), 593-617.

Lüthje, C. \& Franke, N. (2003). "The "Making" of an Entrepreneur: Testing a Model of Entrepreneurial Intent Among Engineering Students at MIT”, R\&D Management, 33(2), 135-147.

McGee, J. E., Peterson, M., Mueller, S. L. and Sequeira, J. M. (2009). "Entrepreneurial SelfEfficacy: Refining the Measure”, Entrepreneurship Theory and Practice, 33(4). pp. 965988.

McLaughlin, E. B. (2010). "The Role of Emotional Intelligence and Self- Efficacy in Developing Entrepreneurial Career Intentions”, Journal of Higher Education Theory and Practice, 19(7): 71-88.

Miranda, F. J., Chamero-Mera, A. and Rubio, S. (2017/a). “Academic Entrepreneurship in Spanish Universities: An Analysis of the Determinants of Entrepreneurial Intention”, European Resarch on Business Economics, (23). pp. 113-122.

Miranda, F., Chamorro-Mera, A., Rubio, S. and Perez-Mayo, J. (2017/b). “Academic Entrepreneurial Intention: The Role of Gender”, International Journal of Gender and Entrepreneurship. pp. 66-86.

Mortan, R. A., Ripoll, P., Carvalho, C. and Bernal, M. C. (2014). "Effects of Emotional Intelligence on Entrepreneurial Intention and Self-Efficacy", Journal of Work and Organizational Psychology, (30). pp. 97-104.

Nabi, G. \& Liñán F. (2013). "Considering Business Start-up in Recession Time (The Role of Risk Perception and Economic Context in Shaping the Entrepreneurial Intent)", International Journal of Entrepreneurial Behavior \& Research, 19(6), 633-655.

Naktiyok, A., Karabey, C. N. and Güllüce, A. Ç. (2010). "Entrepreneurial Self-Efficacy and Entrepreneurial Intention: The Turkish Case”, International Entrepreneurship and Management Journal, 6(4). pp. 419-435.

Nwankwo, S., Gbadamosi, A. and Ojo, S. (2012). Religion, Spirituality and Entrepreneurship. Society and Business Review, 7(2). pp. 149-167.

Ozaralli, N. \& Rivenburg, N. K. (2016). Entrepreneurial Intention: Antecedents to Entrepreneurial Behavior in the U.S.A. and Turkey. Journal of Global Entrepreneurship Research, 6(3), 1-32.

Ören, K. \& Biçkes, M. (2011). Kişilik Özelliklerinin Girişimcilik Potansiyeli Üzerindeki Etkileri (Nevşehir'deki Yüksek Öğrenim Öğrencileri Üzerinde Yapılan Bir Araştırma). Süleyman Demirel Üniversitesi İktisadi ve İdari Bilimler Fakültesi Dergisi, 16(3), 67-86.

Peng, Z., Lu, G. and Kang, H. (2012). Entrepreneurial Intentions and its Influencing Factors: A Survey of the University Students in Xi'an China. Creative Education, (3), 95-100.

Renn, O. \& Rohmann, B. (2000). Cross- Cultural Risk Perception, Netherlands: Kluwer Academic Publishers.

Sabah, S. (2016). Entrepreneurial Intention: Theory of Planned Behaviour and the Moderation Effect of Start-Up Experience. Entrepreneurship-Practise-Oriented Perspectives: 87-101.

Salovey, P. \& Mayer, J. D. (1990). Emotional Intelligence. Imagination, Cognition and Personality, 9, 185-211.

Şeşen, H. \& Basım, N. (2012). Demografik Faktörler ve Kişiliğin Girişimcilik Niyetine Etkisi: Spor Bilimleri Alanında Öğrenim Gören Üniversite Öğrencileri Üzerine Bir Araştırma. EgeAkademik Bakış, (12), 21-28.

Timuroğlu, M. K. \& Çakır, S. (2014). Girişimcilerin Yeni Bir Girişim Yapma Niyetlerinin Risk Alma Eğilimi ile İlişkisi. AKÜ İ̈BF Dergisi, 16(2), 119-136. 
Timuroğlu, M. K. \& Akpunar, E. N. (2017). Duygusal Zekanın Girişimcilik Niyeti Üzerine Etkisi. Atatürk Üniversitesi İktisadi ve idari Bilimler Dergisi, 31(4), 875-894.

Tiwari, P., Bhat, A. K. and Tikoria, J. (2017). The Role of Emotional Intelligence and SelfEfficacy on Social Entrepreneurial Attitudes and Social Entrepreneurial Intentions. Journal of Social Entrepreneurship. pp. 1-21.

Top, S. (2012). Girişimcilik: Keşif Süreci, İstanbul, Beta Basım Yayım Dağıtım A.Ş.

Top, S. (2017). Girişimcilik Niyeti, İstanbul, Beta Basım Yayım Dağıtım A.Ş.

Tsai, K.-H., Chang, H.-C. and Peng, C.-Y. (2016). Extending the Link Between Entrepreneurial Self-efficacy and Intention: A Moderated Mediation Model. International Entreprenerrship and Management Journal, 12 (2), 445-463.

Uslu, D. (2015). Bilgisayar ve Öğretim Teknolojileri Eğitimi Bölümü Öğrencilerinin Girişimci Kişilik Özellikleri ve Girişimcilik Niyetinin Duygusal Zeka Faktörlerine Göre İncelenmesi. (Doktora tezi, Gazi Üniversitesi, Eğitim Bilimleri Enstitüsü, Ankara), Erişim adresi: http://tez.yok.gov.tr/UlusalTez Merkezi/, (07.01.2018).

Van Gelderen, M., M. Brand, C.M. Van Praag, W. Bodewes, E. Poutsma and A. Van Gils. (2008). Explaining Entrepreneurial Intentions by Means of the Theory of Planned Behavior. Career Development International, 13. pp. 538-559.

Wood, R. \& Bandura, A. (1989). Social Cognitive Theory of Organizational Management. The Academy of Manegement Review, 14(3), 361-384.

Xu, X., Ni, H. and Ye, Y. (2016). Factors Influencing Entrepreneurial Intentions of Chinese Secondary School Students: An Emprical Study. Asia Pasific Educational Review, 17(4), 625-635.

Yüksel, H., Cevher, E. and Yüksel, M. (2015). Öğrencilerin Girişimci Kişilik Özellikleri ile Girişimcilik Eğilimleri Üzerine Bir Araştırma. Çankırı Karatekin Üniversitesi İktisadi ve İdari Bilimler Fakültesi Dergisi, 5(1). pp. 143-156.

Zakarevičius, P. \& Župerka, A. (2010). Expressıon of Emotıonal Intellıgence in Development of Students' Entrepreneurship. Economics and Management, (15), 865-873.

Zampetakis, L. A., Kafetsios, K., Bouranta, N. and Bouranta, N. (2009). On the Relationship Between Emotional Intelligence and Entrepreneurial Attitudes and Intentions. International Journal of Entrepreneurial Behaviour \& Research, 15(6). pp. 595-618.

Zhang, P. \& Cain, K. W. (2017). Reassessing the Link Between Risk Aversion and Entrepreneurial Intention. International Journal og Entrepreneurial Behavior\& Resarch, 23(5), 793-811.

Zhao, H., Hills, G. E. \& Seibert, S. E. (2005). The Mediating Role of Self-Efficacy in the Development of Entrepreneurial Intentions. Journal of Applied Psychology, 90(6), 12651272.

Zhao, H., Seibert, S. E., and Lumpkin, G. T. (2010). The Relationship of Personality to Entrepreneurial Intentions and Performance: A Meta-Analytic Review. Journal of Management, 36(2), 381-404. 